[Vicino Oriente XIX (2015), pp. 1-24]

\title{
BETHLEHEM IN THE BRONZE AND IRON AGES \\ IN THE LIGHT OF RECENT DISCOVERIES BY THE PALESTINIAN MOTA-DACH
}

\author{
Lorenzo Nigro - Sapienza University of Rome
}

The discovery of the necropolis of Khalet al-Jam'a, around $2.2 \mathrm{Km}$ south-east of Bethlehem (Nigro et al. in this volume), provides new data on the Bronze and Iron Age town which controlled the main route connecting Jerusalem to Hebron, and the access to the wadiat crossing the southern Judean desert and leading to the coastal plain. Intermediate Bronze Age/Early Bronze IV, Middle Bronze shaft tombs, and at least two major Iron II burial caves (Tomb A7 and the Barmil's Tomb) excavated by the Palestinian MOTA-DACH in an Iron Age cemetery allow to draw up a renewed picture of Bethlehem and its environs and give the opportunity to re-appraise its long history.

Keywords: Bethlehem; Bronze Age; necropolis; Iron Age; David

\section{INTRODUCTION: THE ARCHAEOLOGY OF BETHLEHEM}

Notwithstanding its wide popularity and by opposite in respect of other Biblical and Holy Places in Palestine, Bethlehem has never been exaggeratedly attractive for archaeological investigations, except for the area of the Basilica of the Nativity ${ }^{1}$ and some other convents and churches in its vicinity, ${ }^{2}$ which were the object of explorations since the late antiquity. This is presumably due to the continuous occupation of the site and to the blooming of the modern town concealing pre-existing remains.

Archaeological investigations during the twentieth century, including occasional excavations connected to public or private building works, have been carried out almost exclusively by Franciscan Fathers in the Holy Places and connected installations (the Basilica of the Nativity, surrounding convents, the 'Milk Grotto' and other religious compounds like the so-called 'David's Wells'). ${ }^{3}$ As regards the district of Bethlehem and its role in antiquity, it was explored by surveys, which extension and reliability should be carefully evaluated, taking into account modern development of urbanized areas (fig. 1) and the peppered coverage achieved by these archaeological prospections. ${ }^{4}$

1 In spite of the common tradition in English speaking world to call it "Church of the Nativity", this sacred building bears the rank of "Basilica" and it is, thus, called "the Basilica of the Nativity".

2 Vincent - Abel 1914; Richmond 1936; 1937a; 1937b; Harvey 1937; Bagatti 1952; 1968. Father Bagatti gives a list of Monasteries known from sources: Monastero di Cassiano, Monastero di Posidione e Palladio, Monastero di Giovanni (perhaps the same of one of the latters); Monastero di San Sergio; Monastero di Marciano.

3 Bagatti 1968; Saller 1968; Avi-Yonah 1993; Bagatti - Alliata 1980.

4 Results summarised for example by G. Lehmann (2003) or A. Ofer were based upon data collected in what I diplomatically would describe a somewhat "complicated territorial situation". This kind of evidence could hardly depict a reliable picture of any ancient period, especially for the Iron Age, often too close to invasive successive layers of the Hellenistic and Roman periods. Modern building activities (including the Israeli Wall) and a century of archaeological investigations have drastically and often irremediably modified the available surface material - its distribution and quantity - exploited by such surveys. Actually, many of such publications do not clearly explain what is the very material evidence taken into account, where and when it was collected and how it was sampled and retained representative of ancient occupation. Sites unoccupied in 
A picture of the history and topography of Bethlehem from Roman times onward was offered by Father Bellarmino Bagatti o.f.m. in his monograph, ${ }^{5}$ with a complete list of ancient sources. Father Bagatti gave a reliable and direct description of major archaeological monuments, convincingly reconstructing the original layout of the Medieval town and its transformations through times. Actually, apart from some sparse tombs and the Khalet al-Jam'a Necropolis, this picture is not changed so far since the mid of the last century, even though many monuments were unfortunately destroyed or drastically transformed.

A survey carried out in 1969, accounted in the Revue Biblique, ${ }^{6}$ suggested the possible identification of the Iron Age town of Bethlehem on the eastern and southern slopes of hill of the Basilica of the Nativity. This location seems plausible for the Iron Age IIC-III (701535 BC), while it is not proved for the Middle and Late Bronze Age, as well as for Iron I and IIA-B (1200-701 BC) (fig. 1).

In the following decades, no further archaeological information on the town of Bethlehem was collected, except for some Intermediate Bronze Age/Early Bronze IV tomb assemblages occasionally discovered. ${ }^{7}$

With the establishment of the Palestinian Ministry of Tourism and Antiquities (1994) after the Oslo agreements (1993), the Department of Archaeology and Cultural Heritage in cooperation with the Municipality and several other institutions ${ }^{8}$ started a series of interventions aiming at the protection and safeguard of archaeological remains and historical buildings within the city and in its surrounding area. Monuments and historical sites were enlisted, and many of them were protected or transformed into museums. ${ }^{9}$ This led to the creation of the Olive Oil Production Museum ("al-Badd Giacaman Museum”; fig. 2), the Bethlehem Museum (The Bethlehem Museum for Palestinian Heritage, History and Culture; fig. 3), ${ }^{10}$ the International Nativity Museum (located in the ground floor of the historical Salesian convent), the Bethlehem Peace Center facing on Manger Square, and, finally, to the refurbishing of the Museum of the History of the City of Bethlehem (fig. 4).

A further commitment of Palestinian and international institutions was the restoration of several historical sites, including the three Solomon's Pools (كرب سليمان, Burak Suleīmān) by the village of el-Khader (fig. 5), around $5 \mathrm{Km}$ on the road to Hebron, as well as landscape protection in Wadi Artas (fig. 6), where the Artas Spring was rehabilitated, or, to the west, the picturesque village of Battir (fig. 7), which was included into UNESCO's World Sites List (like the Basilica of the Nativity which is n.1 in Palestine). ${ }^{11}$

modern times (like ancient Tequ'a) may, thus, seem larger than sites, like ancient Bethlehem, which unavoidably lay partially or completely underneath modern urban areas.

5 Bagatti 1952, 234-268.

6 Gutman - Berman 1970.

7 Dadon 1997.

8 Among many cooperation agencies of several countries (Italy, Japan, Norway, etc.) participating into the Bethlehem refurbishing, especially in the occasion of the Year 2000 Jubilee, it is mandatory to mention the Custodia Terrae Sanctae of the Franciscan Fathers, and the UNESCO.

$9 \quad$ Abu Jidi - Diab 1999; el-Hasan 1999; Taha 2010.

10 A Canaanite jar (KJ.15.TA2.1/1) from the necropolis of Khalet al-Jam'a is on display in this recently opened museum (fig. 3 , box on the right).

11 Taha 2012 
Such an overall re-appraisal of the city also beckoned scholars to resume the study of its history and archaeology, as exemplified by two major contributions by Fernand de Cree and Kay Prag reassessing all available data from Bethlehem. ${ }^{12}$ The latter scholar commendably continued her study of Bethlehem also on the field, contributing to a major re-evaluation of this site through history. ${ }^{13}$

In the following fifteen years, renewed building activities and connected excavations brought about a new set of topographic and material data, which deserve a new careful examination, and allow a further series of observations on its historical-archaeological development also in the light of the discovery of the necropolis of Khalet al-Jam'a.

\subsection{Location, topography and water sources}

Located $8 \mathrm{Km}$ south of Jerusalem, on the crest of a spur sloping eastwards from the central Palestinian watershed and of the main Jerusalem - Hebron road, Bethlehem was originally occupied in pre-classical times, as suggested by sparse archaeological finds. Its toponym ("House of meat" in Arabic, "House of bread" in Hebrew) ${ }^{14}$ points in any case to the role of food market in a favourite location in respect of grazing areas and cultivation and exchange of grain, wheat and barley, while Biblical quotations confirm its identification, considering it the southern border of the Jerusalem district, ${ }^{15}$ and attributing it the special role as birthplace of David and Jesus. ${ }^{16}$

Bethlehem arose at a strategic crossroad of the inner dorsal road crossing Judah with two major wadiat sloping down to the Dead Sea, Wadi Ta'amireh and Wadi Khareitun Wadi Mu'allaq, and Wadi el-Jindi - Wadi es-Sant descending towards the coastal plain and the village of Zakariyah (through the Valley of Elah) (fig. 8).

Water supply in Bethlehem is assured by several sources distributed in its immediate surroundings. Six main springs are known: 'Ain Umm al-Daraj; 'Ain Artas; 'Ain Salih; 'Ain Faruja; 'Ain Attan; 'Ain Battir, which gave a valid supply to the communities living in the area since the $4^{\text {th }}$ millennium BC onwards. In pre-classical times, individual hydraulic installations and cisterns were used, while in the Roman period the city and its environs were connected with the main aqueduct carrying waters to Jerusalem, built by the soldiers of the $X$ Legio Fretensis and reconstructed under Septimius Severus (145-211 AD). ${ }^{17}$ The aqueduct drove waters from the Solomon's Pools, the three huge water basins fed up by the springs of Salih, Attan, and Faruja.

Cisterns and pools for drinkable water were spread all over the ancient town. They are mentioned in ancient sources starting from the water pools quoted in the famous Biblical passage of David (2 Sam. 23,15-17; 1 Chron. 11,18), which locates such installations by the

2 De Cree 1999; Prag 2000.

13 Prag 2013.

14 Other interpretation of the toponym Beth-Lehem have been connected with the God Lahmu, known from Assyrian sources, or with the meaning "House of the battle” (Keel - Küchler 1982, 963).

15 Abel 1933, 86.

16 Late Antiquity sources also state that around half mile north of the centre there was a church (Saint David) concealing the tombs of Ezechiel, Asaph, Job, Jesse, David and Salomon, mentioned by Eusebius in the Onomasticon, by Paul the Deacon, the Anonymous from Piacenza and Arculf (Bagatti 1952, 242-243).

17 Vetrali 1967; Prag 2008. 
north gate of the city. Actually, as far as archaeology has demonstrated, the so-called "David's Wells" are three Roman cisterns connected with an early Byzantine church and a catacomb in use in the $4^{\text {th }}-6^{\text {th }}$ century AD. ${ }^{18}$ Water availability in Bethlehem was, thus, not so different from that of other central hilly regions of Palestine where stable and large settlements arose in the Bronze and Iron Ages.

Due to natural conformation of the local carsic limestone, caves and tunnels in the bedrock were used through centuries for tombs, shepherds' shelters, storage facilities, workshops and dwellings. It is, thus, very difficult to date back the earliest utilization of such underground devices, which were re-employed many times by the inhabitants of the town. Only in some cases, the presence of a certain type of shaft, or a dromos, may indicate the funerary utilization, and even the dating of these caves, like in Khalet al-Jam'a.

\section{ThE EARliest SetTlements (NEOlithiC to EARLy BRONZE AgE)}

Apart from the Lower Pleistocene faunal remains retrieved by chance in 1934 digging a well in the north-west area of al-Betan, ${ }^{19}$ which give back an image of Palestine populated by Noah's Ark species (elephant, giraffe, hippopotamus, rhinoceros, lion, etc.), and show traces of human manipulation (marrow extraction), the earliest evidence of human occupation in the Bethlehem district are Neolithic flints retrieved in various areas of the town, and the nearby village of Beit Sahur. ${ }^{20}$ The latter, located $2.4 \mathrm{Km}$ east of the Basilica of the Nativity, apparently hosted the earliest stable community in the Late Chalcolithic period (Ghassulian), living in caves sparse in an area around two hectares. Another inhabited Chalcolithic cave was excavated by the MOTA-DACH south-east of the centre, near the Spring of Artas (M. Ghayyada). It yielded human remains, a pottery assemblage including typical painted cornets, and basalt bowls with high flaring sides.

The Beit Sahur settlement further developed in the Early Bronze I (3400-3200 BC), being arranged on terraces, like in coeval Jerusalem, and exploiting the wide and flat centre of the small valley. ${ }^{21}$ A tomb group in the olive trees grove on the western flank of the wadi may have belonged to the inhabitants of this rural hamlet, and it suggests that the area of Beit Sahur was occupied also during the Early Bronze II and III (3000-2300 BC). A burial cave ${ }^{22}$ discovered within the modern village yielded more than 160 complete vessels including a Khirbet Kerak bowl ${ }^{23}$ - a set considered a possible indicator of an urbanized group. No further elements on the Early Bronze Age occupation are available from Bethlehem, however, an Early Bronze II-III centre may have existed. It may be tentatively located in the area west of the Basilica of the Nativity (on the saddle of Manger Square and on its western side) or slightly to the southwest, overlooking the Artas Spring, as well as to the south-east, on the hilltop just south of the Basilica and the 'Milk Grotto' (§ 4.; fig. 9).

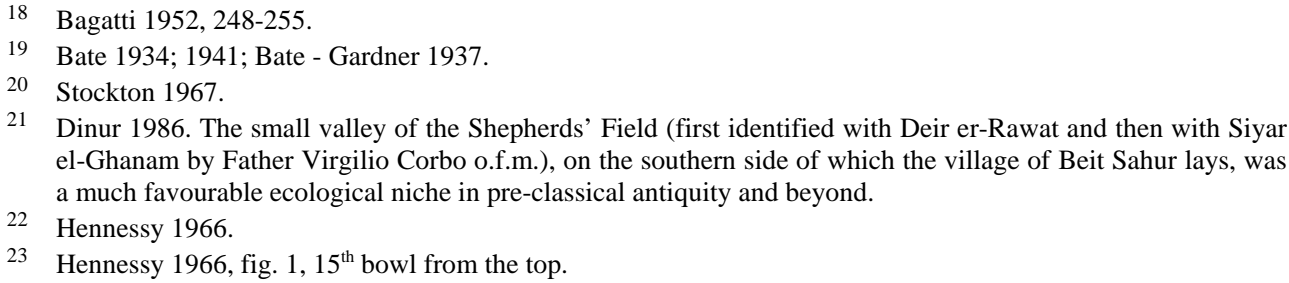


3. Tombs of the Intermediate Bronze Age/Early Bronze IV AND the Role of PASTORALISTS IN THE BETHLEHEM NEIGHBOURS

A group of tombs dating from the Intermediate Bronze Age/Early Bronze IV was discovered in the easternmost fringes of the Beit Sahur hill in 1908-1909. ${ }^{24}$ Together with other sparse burial finds in the area of the camp of Dhaishe (south-west of Bethlehem), along the road to Hebron (at Effrata and Khirbet Kufin), ${ }^{25}$ and, above all, in the newly discovered cemetery of Khalet al-Jam'a (fig. 10), such interments show that in this period farmers-pastoralists not only seasonally settled in the area of the springs feeding Wadi Artas and Wadi Ta'amireh, but also used some rock plateaux on the nearby hills to cut their shaft tombs, living in the small valleys underneath. There again, both wadiat were major transhumance trails respectively along the north-south Palestinian central highway, and between the Bethlehemite Judean hills, the desert and the Dead Sea.

Intermediate Bronze Age/Early Bronze IV ceramic assemblages in Khalet al-Jam'a were found in tombs used also in the following Middle Bronze Age, ${ }^{26}$ thus suggesting a certain continuity in the local community (even though a chronological gap existed), which presumably was protagonist of a small scale urban revival during the $2^{\text {nd }}$ millennium BC.

\section{The NeCropolis of Khalet AL-JAM’A And Bethlehem in the Middle Bronze AGE}

The discovery of a huge necropolis in the sloping hill of Khalet al-Jam'a, just $2.2 \mathrm{Km}$ south-east of the Basilica of the Nativity, on a rocky terrace dominating upper Wadi Ta'amireh (figs. 11-12), shades new light on the history of Bethlehem in the $2^{\text {nd }}$ millennium BC.

In the early spring of 2013, building activities funded by the French government cut through the central area of an at least three hectares-wide cemetery consisting of rock-cut shaft tombs. Unfortunately, many of these tombs suffered complete destruction (fig. 13) or looting before the MOTA-DACH intervention. The necropolis originally hosted at least one hundred shaft tombs, which were dug and used in a time span ranging from Early Bronze IV and Middle Bronze I-III to Iron Age II. The long-lasting utilization, over a millennium and a half or more (2200-650 BC), and the large number of tombs, suggest that Khalet alJam'a (henceforth KJ) was the necropolis of a major settlement in the area, possibly a town, occupied from the Middle Bronze to the Iron Age (apparently with a partial gap in the Late Bronze Age). While Early Bronze IV shaft tombs are a quite common feature of hilly Palestine, even though they can be seldom referred to a specific inhabited site, Khalet alJam'a's Middle Bronze I-III rich tombs (figs. 14-15) should be necessarily related to a major settlement, possibly a town. They show utilization by family groups through generations and inner differentiation as several coeval necropolis (e.g. those of Jericho or Tell el-Far'ah North). Moreover, the necropolis was densely populated, as it is shown by the fact that in several cases shafts cut through pre-existing underground chambers.

Where was this town? Its location can be restricted to the area just north-west of the necropolis, within a radius of maximum $2 \mathrm{Km}$. One has to take into consideration the

4 Hänsler 1908; 1909; Vincent 1909, 116; Wright 1938.

25 Smith 1962

26 Nigro et al. 2015, Tombs B9, B10, C12. 
locations of the springs which necessarily assured a valid water supply to the town. They are mainly concentrated at the head of Wadi Artas, thus suggesting to locate Middle Bronze Age Bethlehem just north-east of the Artas spring on the mounds overlooking this fertile compound, south-west of the Basilica of the Nativity (fig. 8). Actually, Wadi Artas ends just at the foot of the hill upon which the KJ necropolis is located: it thus would be a suitable place for the MB town. However, no remains are visible there. A location further north, on the uppermost crescentic hill west of Manger Square, underneath the centre of the still living town, seems, instead, the most probable one, as Father Bagatti rightly pointed out: «the village of Bethlehem always stood in the same place, since the steep flanks of the hill formed a natural defence». ${ }^{27}$ The continuous superimpositions of settlements since the $2^{\text {nd }}$ millennium BC, would also explain why such an early phase was largely obliterated by successive ones. The western hill, in facts, became the main town since Roman times, after the transformation of the original Iron Age settlement (the hill of the Basilica of the Nativity) into a cult place. The location of the town on the western hill, i.e. on the central watershed, also accomplished to a second need which was to control the main JerusalemHebron road at its bifurcation towards Wadi Ta'amireh (to the Dead Sea) and Wadi Khareitun (to Tequ'a).

Taking into consideration the tombs assemblages of Khalet al-Jam'a, they depict a rich and variegated society. This may reflect the city wealth, and its role on the way to the south along the inner Palestinian main southern highway. Typical pieces of the burial sets are finely executed carinated bowls, small shouldered jars/bowls with everted rim, one-spouted lamps, huge and well refined Canaanite jars with two or four handles, as well as bronze daggers and spearheads, with typical spherical pommels on their handles, and "Hyksoslike” signet scarabs mounted on bronze or golden rings.

As regards the Late Bronze Age, in spite of some sparse finds in tombs, which actually may indicate that the town was still inhabited in this period, however, there is no positive evidence in support of its identification with the hypothesized "Beth Lahmi" in the Amarna Letters. ${ }^{28}$ The latter reading was in facts rejected by scholars. Nonetheless, finds in the KJ necropolis may suggest that the Middle Bronze centre continued also in the Late Bronze until the Iron Age.

\section{BethleHEM IN THE IRON AgE AND THE BARMIL’s TOMB IN THE KJ NECROPOLIS}

In the Iron Age, the existence of a stronghold or a small town, marking the southern border of the Jerusalem district, at the joint of the dorsal highway with the western (Wadi Jindi) and eastern (Wadi Ta'amireh) tracks climbing the mountain of Judah up to Jerusalem, is indicated by a number of finds spread over the whole area of the modern city and its neighbours.

27 Bagatti 1952 (author’s translation from Italian); Cagiano de Azevedo 1952

28 ANET, 489, EA 290. 


\subsection{The arrowheads form el-Khadr and early Iron Age in Bethlehem}

The Iron Age in Bethlehem is announced by five sound pieces of evidence: ${ }^{29}$ five inscribed bronze arrowheads retrieved in the south-western suburb of el-Khadr (fig. 16) between 1954 and 1980, possibly in an Iron Age tomb, within a hoard or a cult offering (since they were grouped). They are amongst the earliest documents written in alphabetic letters found in Palestine, and they might acknowledge the origin of the alphabet from this region. ${ }^{30}$ They date back from the second half of the $11^{\text {th }}$ century $\mathrm{BC}$, also showing the long persistence of a common Late Bronze arrowhead type. Personal names inscribed have been related to the Levantine Goddess 'Anat, who is also directly mentioned in the fifth inscribed specimen (bn 'Anat, "son of 'Anat") or referred to indirectly in another specimen told to belong to Abd Labiat, "the servant of the lioness [-goddess]". Although such a divine name may suggest a different origin of the arrowheads from Syria or Lebanon, one cannot rule out the possibility of their provenance from a sanctuary of the goddess located in the ancient city of Bethlehem or in its neighbours. ${ }^{31}$ The cult of a female mother/pregnant goddess in antiquity in the area of Bethlehem may be hinted at by other finds (figurines), and echoed by holy places like Rachel's Tomb and the Old Kathisma Church on the way from Jerusalem (near Mar Elias' Monastery and Ramat-Rahel). ${ }^{32}$

As regards the occupation of the city in this period, two collared rim jars fragments were found in the excavations of the so-called "David's Wells" in 1968 (fig. 17), ${ }^{33}$ an area which is thought to be near to the north gate of the ancient town. They were, however, out of the original archaeological context.

\subsection{Iron Age tombs in Bethlehem and the Barmil's Tomb in the Khalet al-Jam'a necropolis}

Iron Age tombs discovered south, east and north of the centre of the town, point to a superimposition of the Iron IIA-B (960-701 BC) settlement over the Middle and Late Bronze Age town, while Iron IIC-III tombs and sparse finds, indicated that the town expanded over the eastern hill (that of the Basilica of the Nativity).

Iron Age II-III tombs basically consisted of carefully cut chambers with benches and ossuaries, similar to those known in Jerusalem. Funerary assemblages included terracottas, jewellery and weapons, as well as pottery and calcite unguentaria. ${ }^{34}$

The KJ necropolis also included an Iron Age cemetery, extended in Area D, in the northern uppermost terrace of the hill slope. ${ }^{35}$ An Iron II tomb, located to the west in respect of the main Iron Age burial ground, in the Barmil's Family yard, has provided a

29 Sass 1988, 73-78, 148, fig. 17, ns. 185-195.

30 They have been recently re-attributed to a somewhat later stage during the formation of the alphabet (Finkelstein - Sass 2013), towards the end of Iron IB and the beginning of Iron IIA (1050-960 BC).

31 One has, of course, to reject the imaginative reconstruction by B. Mazar that the arrowheads would have belonged to a special bowmen corpus of King David (Mazar 1963).

32 Avner-Levy 2006-2007; Brubaker - Cunningham 2011, 24-28.

33 Bagatti - Alliata 1968, fig. 4, ns. 1-2.

34 Finds from a tomb identified close to Rachel's Tomb, donated by Rev Joseph Barclay to the British Museum (Tubb 1980), may depict a typical furnishing of this period.

35 Tomb A7 was an exception, being located at the easternmost edge of Area A, in the nearby of an IA tower. 
rich comparative assemblage. ${ }^{36}$ The funerary furnishings were copious, including typical Iron IB and IIA-B pottery shapes. An Iron IIA jug may well epitomize such chronological horizon (fig. 18). This pottery material speaks for a continuity of the occupation of Bethlehem from the Bronze to the Iron Age, as well as for the identification of KJ with one of the main necropolis of the city.

\subsection{Iron Age Bethlehem in the Bible}

To understand the Biblical author's perspective may indicate if and how to cope with historical information concealed into the accounts related to Bethlehem.

In spite of some quotations clearly indicating that it was not an Israelite city, ${ }^{37}$ and possibly hosted a Philistine stronghold in Iron I, ${ }^{38}$ Bethlehem received a major relevance in the Old Testament as birthplace of David. The Book of Ruth and 1 Sam. 16 set the scenario for his ascent from the "Root of Jesse", and the Bethlehemite region is the land where, according to the most accredited historical interpretations, ${ }^{39}$ David's history is set: he built up his leadership as chief of a gang, which allowed him to extend his power first to the whole Judah (being enthroned in Hebron) and then, after alliance with the Benjaminites, to conquer Jerusalem, becoming the king of Judah and Israel. The role attributed to Bethlehem might be connected either with the Yahwistic source, or with the original role of this leader, who actually was able in gathering tribes living in the wadiat of Judah and in submitting the central hills up to the border with the Philistines. His reign never exceeded, however, the supposed living areas of the three tribes of Judah, Benjamin and Ephraim, that is to say, from Tappuah - Shiloh to the north to Hebron to the south. This is in an extreme synthesis what scholars reconstructed from the Bible on Bethlehem and David.

Coming to a more direct archaeological concern, this might be grasped from a reference in 2 Chron. 11:6, stating that the city was fortified by king Rehoboam, after the reign division. The identification of a city-wall or something similar from this period was thus deemed relevant by (Biblical) archaeologists. ${ }^{40} \mathrm{~A}$ major structure found in trenches excavated on the central saddle at Manger Square was claimed to be part of such a fortification. However, the dig was backfilled and no data are available to confirm such an interpretation and dating. ${ }^{41}$

36 See Nigro et al. 2015, figs. 31-32.

37 An exemplary story in the Book of Judges (17:7-9; 19:1-18) tells of a Levite having taken a concubine from Bethlehem. The woman had escaped from their village in Ephraim returning to Bethlehem, but the Levite succeeded in bringing her back. While resting near Gibeah (the text specifies: 'an Israelite city'), the woman was raped by local inhabitants and died. Then the Levite, reached home, cut up the body of his concubine shipping her limbs all around Israel as a memento of what should had never been happened. This rather obscure tale, which also insists on the positive attitude of the Bethlehemite father in-law of the Levite, who shows an exquisite hospitality, is taken as a proof of the establishment of the Israelites in the central hills. Actually, it clarifies that both Jebus (Jerusalem) and Bethlehem were not Israelite cities.

38 According to 2 Sam 23:14-16 a Philistine garrison was also in Bethlehem near the northern gate of the city (see below in the main text).

39 Liverani 2003, 104-109.

40 Benoit 1975, 63.

41 Finds in the nearby Peace Centre may support a significantly later date for the structure (Justinian was possibly the responsible of a major refurbishing of the town fortification, see below). 


\subsection{Iron Age II-III Bethlehem in archaeology}

Archaeological data gathered so far are restricted to funerary evidence and can only partially support the coeval site identification. Finds in caves ${ }^{42}$ on the easternmost slopes of the Bethlehem ridge suggested the hypothesis of an Iron Age II-III occupation east and south of the Basilica of the Nativity and by the 'Milk Grotto', ${ }^{43}$ but no structures were actually uncovered confirming this location of the town. Other sparse tombs, ${ }^{44}$ like the Barmil Tomb in the KJ necropolis and other tombs excavated attest to the presence of rich families in the Iron IIB, when the town played an administrative role at the southern border of the Jerusalem district. This function is perhaps indicated also by a $I m l k$ jar sealing ${ }^{45}$ found on the slope north of the Basilica of the Nativity.

In the $7^{\text {th }}$ century BC, the city was still included into the royal Judean administrative system, as it was demonstrated by a bulla (fig. 19) recently retrieved in Jerusalem, mentioning Beth Lehem. ${ }^{46}$

In Iron III, during the Neo-Babylonian and Persian Periods, few data are available, as well as on the early Hellenistic one. Although we have almost no direct evidence on the Neo-Babylonian impact on this area, it seems that the town suffered a crisis. ${ }^{47}$ The only available source is again the Bible which gives the list of returnees to Bethlehem (Ezra 2:21; Neh. 7,25-26). This information, however, apparently reflects a later post-exilic, Hellenistic, scenario. ${ }^{48}$

6. Bethlehem in the Hellenistic, Roman and Byzantine Periods: Helena, Jerome AND THE BEGINNING OF 'HOLY ARCHAEOLOGY'

During the Hellenistic Period Bethlehem disappears in sources to show up again with Jesus's birth during Roman domination. ${ }^{49}$ A khokim tomb, found in Beit Sahur, dating from the $1^{\text {st }}$ century BC, is considered a witness of the spreading of this kind of Jewish hypogea. ${ }^{50}$ In the same period, the erection by the Roman $X$ Legio Fretensis of the Lower Aqueduct, connecting all the major water sources to Jerusalem, is an indirect hint at the town revival. ${ }^{51}$ The absence of other archaeological data for this phase does not imply that the site was reduced to a village, as it seems contradicted by the fact that it was a seat for registering people during the census of Publius Sulplicius Quirinius, governor of Syria (6 $\mathrm{AD}$ ). The only source available for the $2^{\text {nd }}$ and $3^{\text {rd }}$ century $A D$, is Jerome, who states (Ep. 58,3 ) that after the Second Jewish Revolt (135 AD), Hadrian established a shrine with a

42 One of the tombs on the eastern slope has a monumental entrance, inner benches and an ossuary.

43 Bagatti 1952, 261, figs. 106:3, 107:3; 262-263 fig. 108:2.

44 Tubb 1980.

45 Lipschits - Sergi - Koch 2011, 17.

46 According to the excavator (E. Shukron) such bulla is a fiscal fiche belonging to the taxation system of the Kingdom of Judah during the late $8^{\text {th }}-7^{\text {th }}$ century BC.

47 A place is mentioned in Jer. 41:17, “Geruth-Chimàm”, told to be “aside Beth-Lehem”. It has been suggested to identify it with the picturesque village of Battir (Prag 2013, 106).

48 Finkelstein 2010

49 Luke 1-2; Matt 2:1.

50 Pottery material from the Herodian period was also found in cave burials underneath the Basilica of the Nativity (Bagatti 1968, figs. 27-28).

51 Prag 2008; 2013, 107. 
sacred trees grove devoted to the cult of Adonis over the same cave where Jesus born. This possibly was due to the Emperor's policy of replacing Jewish (and Christian) cult places with Roman ones. At that time, Adonis' cult was connected with the just established worship of Antinous, Hadrian's deified pupil, who was drowned into the Nile. As a resurging god, Adonis was possibly considered the nearest to Jesus to take His place (Origen Cels. 5,63). Empress Helena, Constantine's mother, and his strongest inspirer, resumed the sacred cave and began to build up the Basilica in 326. It was completed around 330 and dedicated in 339. ${ }^{52}$ The Basilica compound, including three churches and the monasteries arising around it, supported a strong rebirth of the town, and attracted a long list of pilgrims who mention and describe Bethlehem as an iconic small rural town (a 'villula'). ${ }^{53}$ By the end of the $4^{\text {th }}$ century AD (384-386), Bethlehem also became the residence of Jerome (Eusebius Sophronius Hieronymus; fig. 20), who translated the Bible into Latin (the 'Vulgata') and lived in his hermit's cell and monastery (nowadays the Monastery of Saint Catherine, aside the Basilica) until his death in $420 .{ }^{54} \mathrm{He}$ contributed to the reconstruction of the ancient (Biblical) history of Palestine, and to the identification and preservation of Christian Holy Places and cultural traditions as established by Helena.

In 529 the Constantinian Basilica was destroyed during the Samaritan Revolt, and in 531 it was rebuilt by Justinian as St. Mary Theotokos with the five-aisled basilical plan and a triple apse in place of the previous octagonal one. The underground caves were also rehabilitated and set up as holy places. Justinian also rebuilt the town walls, regularizing the central saddle and unifying the western mound of the Basilica and 'Milk Grotto' with the rest of the city, ${ }^{55}$ at that time populated by monasteries and churches. ${ }^{56}$ With the $6^{\text {th }}$ century, the town flourished as a fixed target of pilgrimages and as seat of monks and hermits, even though it never became a bishop chair (this may justify is minor evidence in the Madaba map). During the 614 invasion by Chosroes II, the Nativity was the only Basilica erected by Constantine to be kept safe because Sasanian soldiers discovered a mosaic depicting the three Magi wearing "Persian” clothes.

\section{BETHLEHEM AFTER THE ADVENT OF ISLAM, DURING THE LATIN KINGDOM AND BEYOND}

With the surrender of Patriarch Sophronius to Caliph Umar (634-644) and the conquest of Jerusalem in April 637 AD, also Bethlehem passed under the control of the ar-Rashidah Caliphate. ${ }^{57}$ Umar flew to Bethlehem to guarantee cult freedom and respect for the

52 Eusebius, Bishop of Caesarea (260-339 AD), living in the same times, in his masterwork, the Onomasticon, lists in Bethlehem the tombs of Jesse and David, as well as the Tower of Edoer [Tower of the herd] (Onom. 196), in the place where Rachel died (Gen 35:19-21), traditionally located at the bifurcation of the road which leads from Jerusalem to Bethlehem. His source was, however, the Bible itself.

53 They are listed by Father Bagatti: Origen, Eusebius, Pilgrim from Bordeaux, Egeria, Jerome, Teodosius, Anonymous Pilgrim from Piacenza, Arculf, Willibald, Eutychius, al-Mukadassi (http://www.betlemme. custodia.org/default.asp?id=588).

54 In $416 \mathrm{AD}$ monastries near the Basilica were set on fire by followers of the Pelasgian heresy, but Jerome escaped death (Ep. 135-137).

55 Procopius, De aedificis V, 9:12.

56 Justinian also restored the monastery of Abbot John: De aedificis, V,9:13.

57 According to Qur'an (17:1), Prophet Muhammad visited Bethlehem during His Nighty Journey (ira') to AlAqsa (Jerusalem): La Strange 1890, 89. 
Basilica, reserving a space in the southern transept to Muslim worship. ${ }^{58}$ This tradition of respect was kept under the Umayyad Caliphate, as it was congenial to their policy, and lasted for three centuries until the Fatimid al-Hakim (985-1021), who let the Basilica to be completely destroyed in 1009. ${ }^{59}$ By those times, Arab travelers and writers visited Bethlehem and described it as a small pleasant village until the Crusaders' reconstruction as a town. ${ }^{60}$ During the Latin Kingdom (1099-1187 BC) and beyond, the city flourished. ${ }^{61}$ Byzantine Emperor Manuel I Comnenus (1143-1180) dressed the Basilica with sparkling wall mosaics around the mid of the twelfth century. With the Islamic recapture and the arrival of Franciscan Fathers, the Basilica maintained its functions and it was preserved almost unmodified until the last century, passing also under Greek Orthodox and Armenian rule until Napoleon. The original tradition of religious tolerance survived through centuries. Bethlehem and Beit Sahur were mixed Muslim and Christian towns for more than a millennium. ${ }^{62}$ For this reason, in spite of its smallness, Bethlehem was chosen as world emblem of peace in Year 2000 by the Palestinian National Authority. ${ }^{63}$

In 2002 the Basilica of the Nativity was again under siege, and in 2012 the city area of Bethlehem was set apart by a new wall. This paper aims at fixing the memory of a shared past to be preserved for the future. May History write a new positive page for Bethlehem and Palestine.

\section{REFERENCES}

ABEL, F.-M.

1933 Géographie de la Palestine, Tome I: Géographie physique et historique, Paris 1933.

ABu Aemar, I. - CaRvajal, C.

2011 The pottery of Khirbet Beit Bassa: Medieval Ceramics Journal 36 (2011), pp. 1-12.

ABU JiDI, N. - DiAB, M.

1999 La restauration des zones archéologiques et des bâtiments historiques de Bethléem: Avi-YonaH, M. Dossiers de Archéologie 240 (1999), p. 88.

1993 Bethlehem: E. STERN (ed.), The New Encyclopaedia of Archaeological Excavations in the Holy Land, Volume I, Jerusalem 1993, pp. 205-208.

AVNER-LEVY, R.

2006-2007 The Kathisma: A Christian and Muslim Pilgrimage Site: ARAM 18-19 (2006-2007), pp. 541-57.

58 In memory of this event in 1860 a beautiful mosque was erected on the opposite side of the Basilica of Nativity facing on 'Manger Square'.

59 In spite of an agreement with the Constantine IX for the reconstruction of the church, this became one of the claimed reasons for the First Crusade in 1099.

60 Abu Ishak e-Farisi el-Istakhri in 951 e al-Mukadassi in 985 (Bagatti 1952, 232).

61 The Arab writer Yâqût depicts it in 1225 as a prosperous and densely populated town (Bagatti 1952, 233).

62 Upper Wadi Ta’amireh and Wadi Khareitun formed a flourishing rural district, as shown by Khirbet el-Bassa (Abu Aemar - Carvajal 2011) and Tequ'a, which was the main centre of the area from the Mameluks onwards.

63 «O Bethlehem parva, sed jam magnificata a Domino!» S. Bernardus Claravallensis Abbati, In vigilia nativitatis Domini, Sermo I,4. 
BAGATTI, B. O.F.M.

1952 Gli antichi edifici sacri di Betlemme in seguito agli scavi e restauri praticati dalla Custodia di Terra Santa (1948-51) (Studium Biblicum Franciscanum Collectio Maior 9), Gerusalemme 1952.

1968 Recenti scavi a Betlemme (Grotte di S. Girolamo; cisterne di David): Liber Annuus 18 (1968), pp. 181-237.

Bagatti, B. - Alliata, E.

1980 Scavo ai “Pozzi di Davide” a Betlemme: Liber Annuus 30 (1980), pp. 259-262.

BATE, D.M.A.

1934 Discovery of a Fossil Elephant in Palestine: Nature 134 (1934), p. 219.

1941 The Bone-Bearing Beds of Bethlehem: Nature 147 (1941), p. 783.

BATE, D.M.A. - GARDNER, E.W.

1937 The Bone-Bearing Beds of Bethlehem: Their Fauna and industry: Nature 140 (1937), pp. 431-433.

BENOIT, P.

1975 L'emplacement de Bethléem au temps de Jésus: Dossier d'Archéologie 10 (1975), pp. 5863.

BRUBAKER, L. - CUNNINGHAM M.B.

2011 The Cult of the Mother of God in Byzantium, Farnham 2011.

CAGiano DE AZEVEDO, M.

1952 Recensione a: P. Bagatti, Gli antichi edifici sacri di Betlemme del Padre Bellarmino CREE, F. DE Bagatti: Aevum 26 (1952), pp. 376-378.

1999 History and Archaeology of Bēt Sāhūr Region. A Preparatory Study for a Regional Survey (The Bethlehem Archaeological Project): Zeitschrift des Deutschen PalästinaVereins 115 (1999), pp. 59-84.

CROSS, F.M.

$1980 \quad$ Newly Found Inscriptions in Old Canaanite and Early Phoenician Scripts: Bulletin of the American Schools of Oriental Research 238 (1980), pp. 1-20.

DADON, $\mathrm{M}$.

1997 A Burial Cave of the Middle Bronze Age I at Giv’at Ze’ev: ‘Atiqot 32 (1997), pp. 51, $199^{*}-201^{*}$.

DINUR, U.

1986 Bethlehem: Excavation and Survey in Israel 5 (1986), pp. 15-16.

FINKELSTEIN, I.

2010 The Territorial Extent and Demography of Yehud/Judea in the Persian and Early Hellenistic Peridos: Revue Biblique 117 (2010), pp. 39-54.

FinKELSTEIN, I. - SASS, B.

2013 The West Semitic Alphabetic Inscriptions, Late Bronze II to Iron IIA: Archaeological Context, Distribution and Chronology: Hebrew Bible and Ancient Israel 2.2 (2013), pp. 149-220.

GUTMAN, S. - BERMAN, A.

1970 Bethléem: Revue Biblique 77 (1970), pp. 583-585.

HÄNSLER, P.

1908 Archäologisches aus Jerusalems Umgebung: Das Heilige Land 52 (1908), pp. 187-193.

1909 Archäologisches aus Jerusalems. Gräberfunde: Das Heilige Land 53 (1909), pp. 32-33.

HARVEY, W.

1937 Bethlehem, Nativity Church: Archaeologia 87 (1937), pp. 7-17. 
EL-HASAN, N.

1999 Le Programme Bethléem 2000: Dossiers d'Archéologie 240 (1999), p. 89.

HENNESSY, J.B.

1966 An Early Bronze Age Tomb Group from Beth Sahur: Annual of Department of Antiquities of Jordan XI (1966), pp. 19-40.

KEEL, O. - KÜCHLER, M.

1982 Orte und Landschaften der Bibel. Ein Handbuch der Studien Reisführer zum Heiligen Land. Der Süden: Vol. II, Zürich 1982.

LA STRANGE, G.

1890 Palestine under the Moslems. A Description of Siria and the Holy Land from A.D. 650 to 1500. Translated from the Works of the Medieval Arab Geographers, London 1890.

LEHMANN, G.

2003 The United Monarchy in the Countryside: Judah and the Shephelah during the 10th Century BCE: A.G. VAughn - A.E. Killebrew (eds.), Jerusalem in Bible and Archaeology: The First Temple Period, Atlanta 2003, pp. 117-162.

LIPSCHITS, O. - SERGI, O. - KOCH, I.

2011 Judahite Stamped and Incised Jar Handles: A Tool for Studying the History of Late Monarchic Judah: Tel Aviv 38 (2011), pp. 5-41.

LIVERANI, M.

$2003 \quad$ Oltre la Bibbia. Storia antica di Israele, Bari 2003.

MAZAR, B.

1963 The Military Elite of King David: Vetus Testamentum 13 (1963), pp. 310-320.

MiLIK, J.K. - CROSS, F.M.

1954 Inscribed Javelin-Heads from the Period of the Judges: A Recent Discovery in Palestine: Bulletin of the American Schools of Oriental Research 134 (1954), pp. 5-15.

NAVEH, J.

1982 Early history of the alphabet: an introduction to West Semitic epigraphy and palaeography, Jerusalem 1982.

Nigro, L. - MonTANARI, D. - GHAYYADA, M. - YASINE, J.

2015 Khalet al-Jam'a. A Middle Bronze and Iron Age necropolis near Bethlehem (Palestine): Vicino Oriente XIX (2015), pp. 185-218.

PRAG, K.

2000 Bethlehem: A Site Assessment: Palestine Exploration Quarterly 132 (2000), pp. 169-181.

2008 R.W. Hamilton, D.C. Baramki and the Lower Aqueduct at Bethlehem: Palestine Exploration Quarterly 140 (2008), pp. 27-38.

2013 Bethlehem: D.M. MAster (ed.), The Oxford Encyclopedia of the Bible and Archaeology, Volume I, Oxford 2013, pp. 104-110.

RICHMOND, E.T.

1936 Basilica of the Nativity: Discovery of the Remains of an Earlier Church: Quarterly of the Department of Antiquities in Palestine 5 (1936), pp. 75-81.

1937a The Church of the Nativity: The Plan of the Constantinian Building: Quarterly of the Department of Antiquities in Palestine 6 (1937), pp. 63-66.

1937b The Church of the Nativity: Alterations Carried out by Justinian: Quarterly of the Department of Antiquities in Palestine 6 (1937), pp. 67-72.

SALLER, S.J.

1968 Iron Age Remains from the site of a new school at Bethlehem: Liber Annuus 18 (1968), pp. 153-180. 
SASS, B.

1988 The Genesis of the Alphabet and its Development in the Second Millennium B.C. SMITH, R.H.

$1962 \quad$ Excavations in the Cemetery at Kufin. Palestine, London 1962.

STOCKTON, E.D.

1967 The Stone Age of Bethlehem: Liber Annuus 17 (1967), pp. 129-148.

TAHA, $\mathrm{H}$.

2010 The Current State of Archaeology in Palestine: Present Pasts 1 (2010), pp. 16-25.

2012 The Story of Inscribing Bethlehem on the World Heritage List: This Week in Palestine 172 (2012), pp. 6-12.

TUBB, J.N.

1980 An Iron Age II Tomb Group from the Bethlehem Region (British Museum Occasional Paper 14), London 1980.

VETRALI, L.

1967 Le iscrizioni dell'acquedotto romano presso Betlemme: Liber Annuuss 17 (1967), pp. 149-161.

VINCENT, $\mathrm{H}$

1909 Chronique - Bethléem: Revue Biblique (1909), pp. 109-127.

VINCENT, H. - ABEL, F.-M.

1914 Bethléem. Le Sanctuaire de la Nativité, Paris 1914.

WRIGHT, G.E.

1938 The Chronology of Palestinian Pottery in Middle Bronze I: Bulletin of the American Schools of Oriental Research 71 (1938), pp. 27-34. 


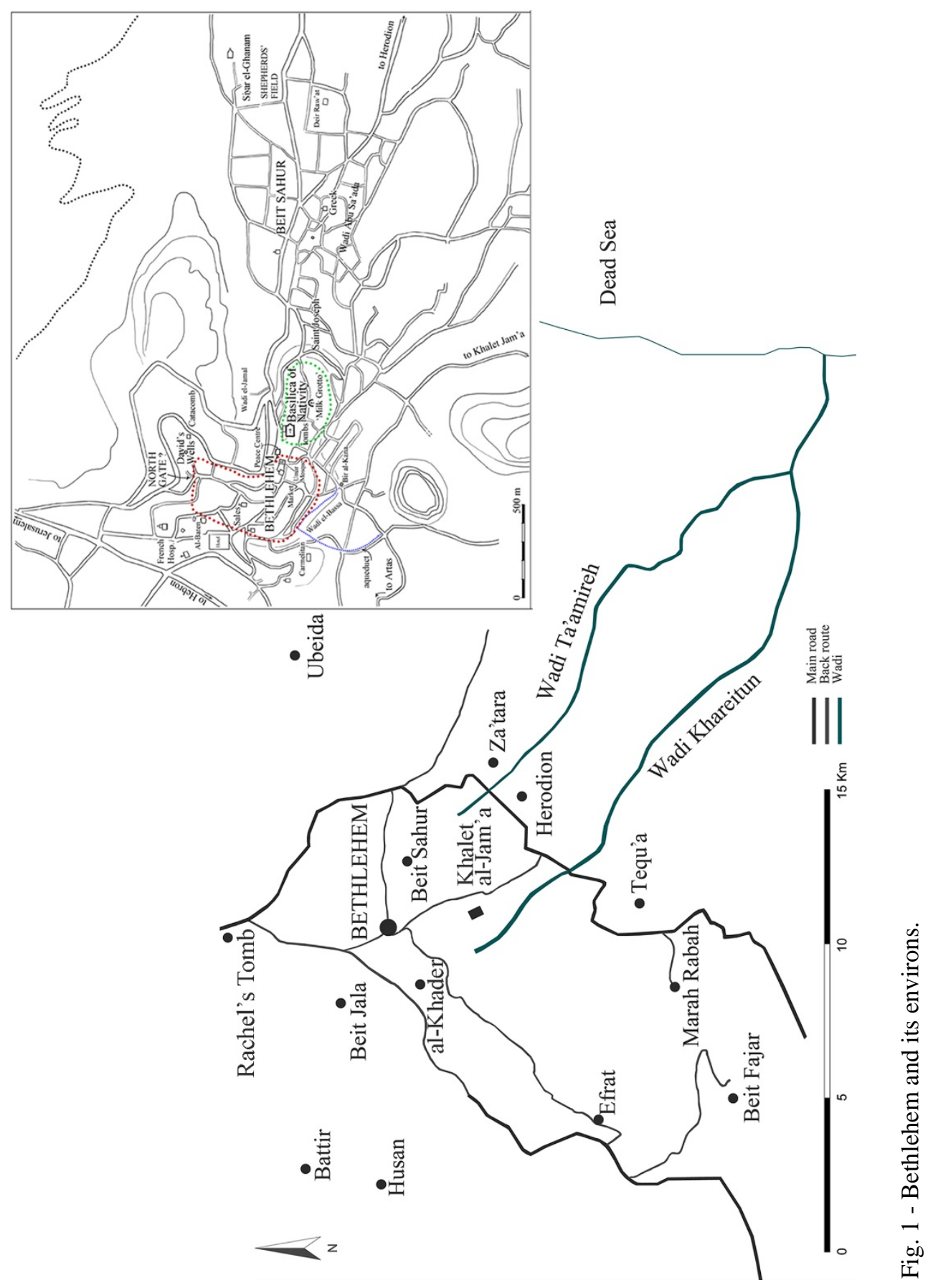



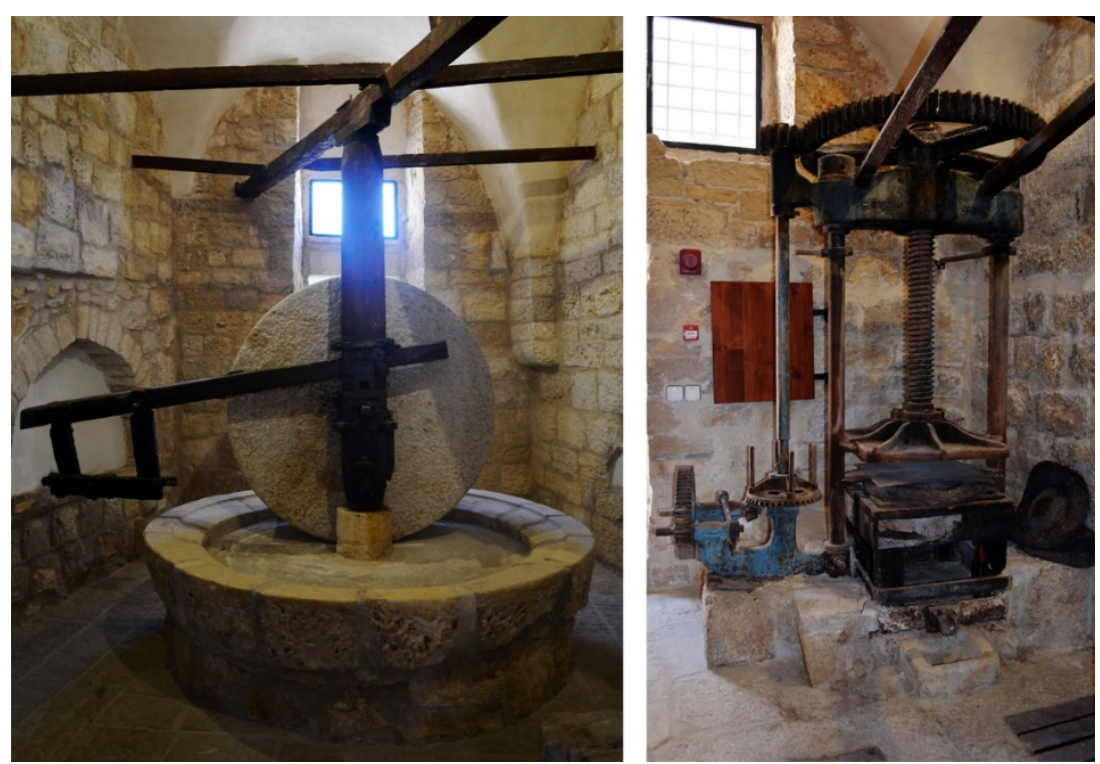

Fig. 2 - The Olive Oil Production Museum “al-Badd Giacaman Museum”.

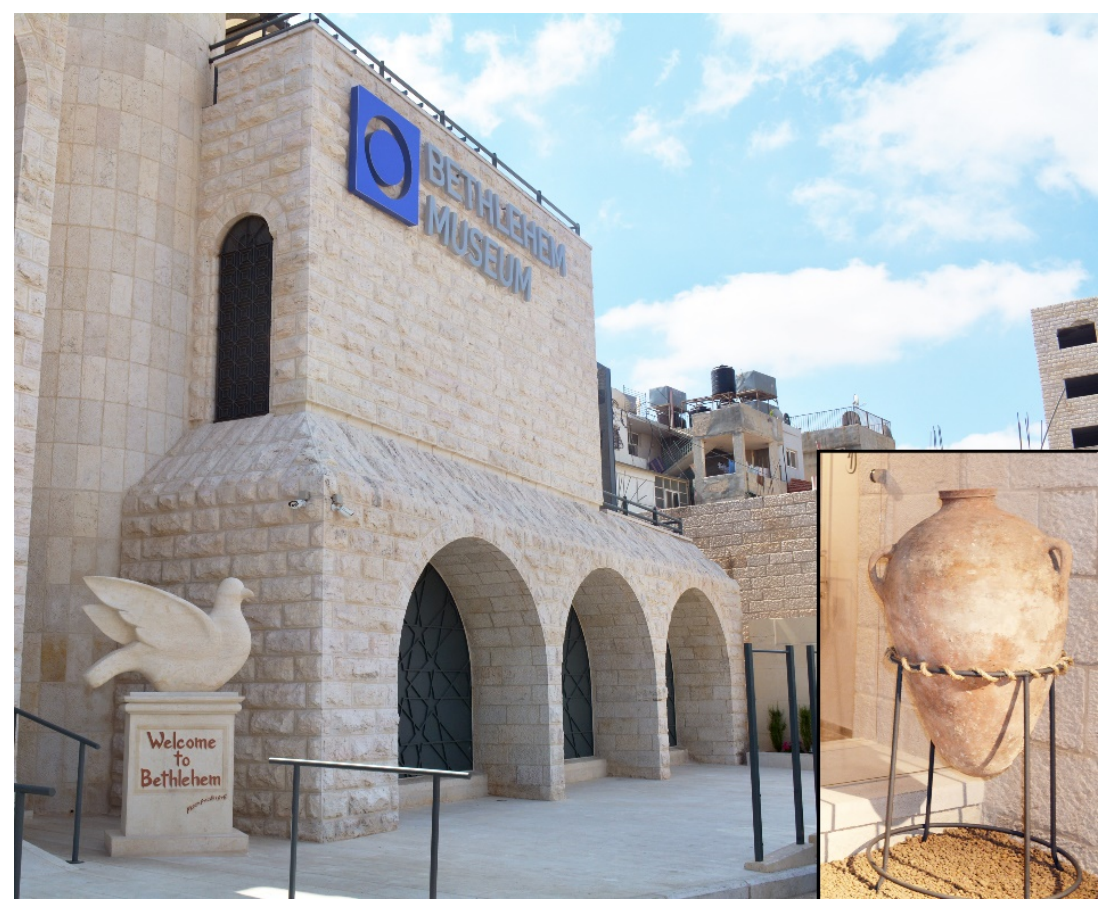

Fig. 3 - The Bethlehem Museum and a MB jar from the necropolis of Khalet al-Jam'a on display. 

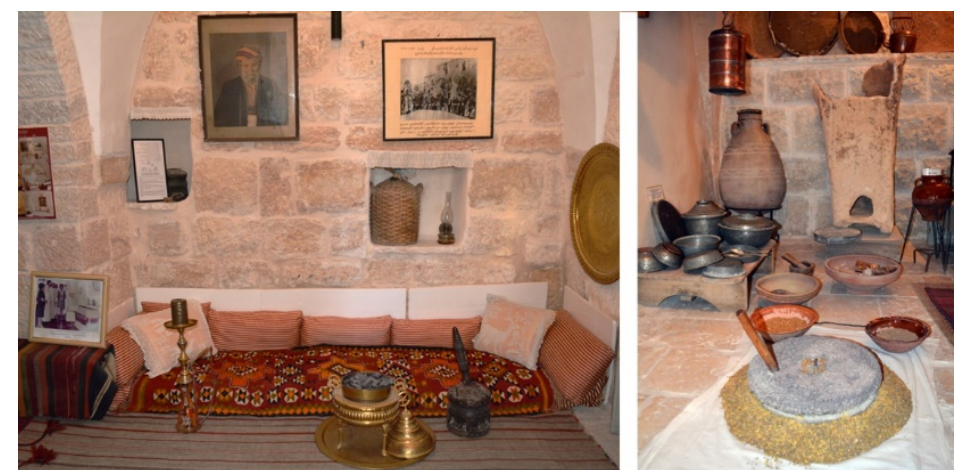

Fig. 4 - The Museum of the History of the City of Bethlehem.
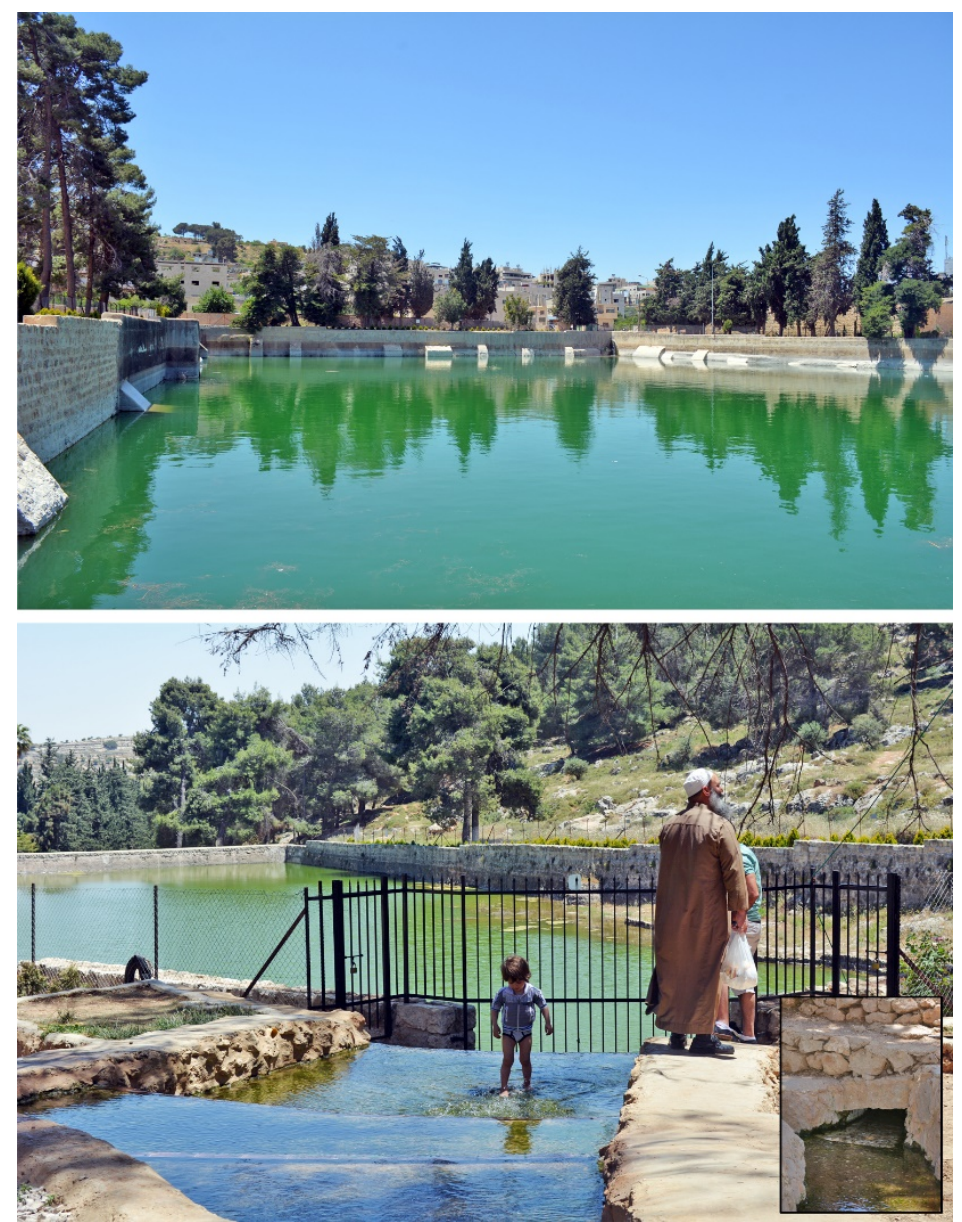

Fig. 5 - First (up) and second (down) Solomon’s Pool. 


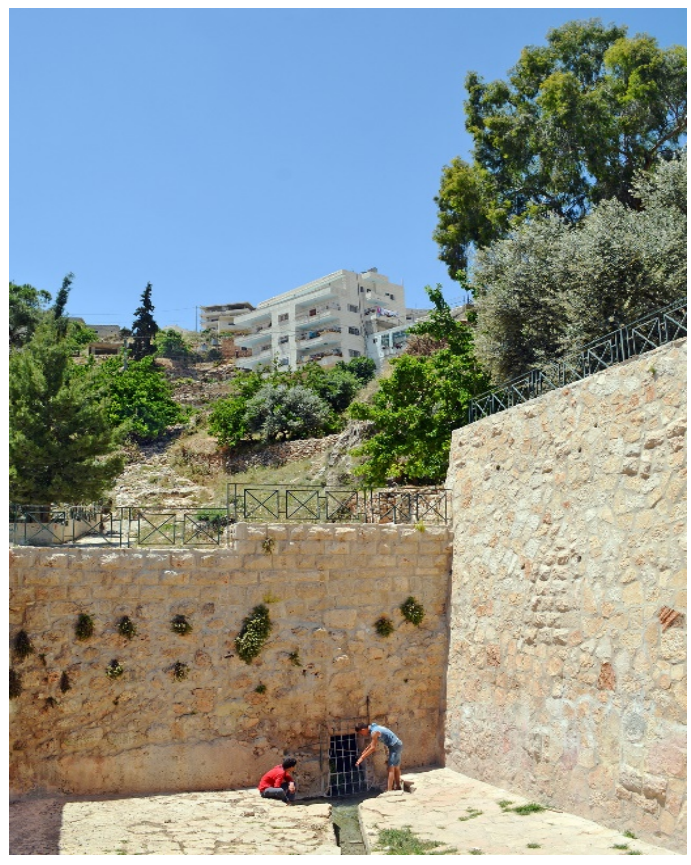

Fig. 6 - Artas Spring rehabilitated.

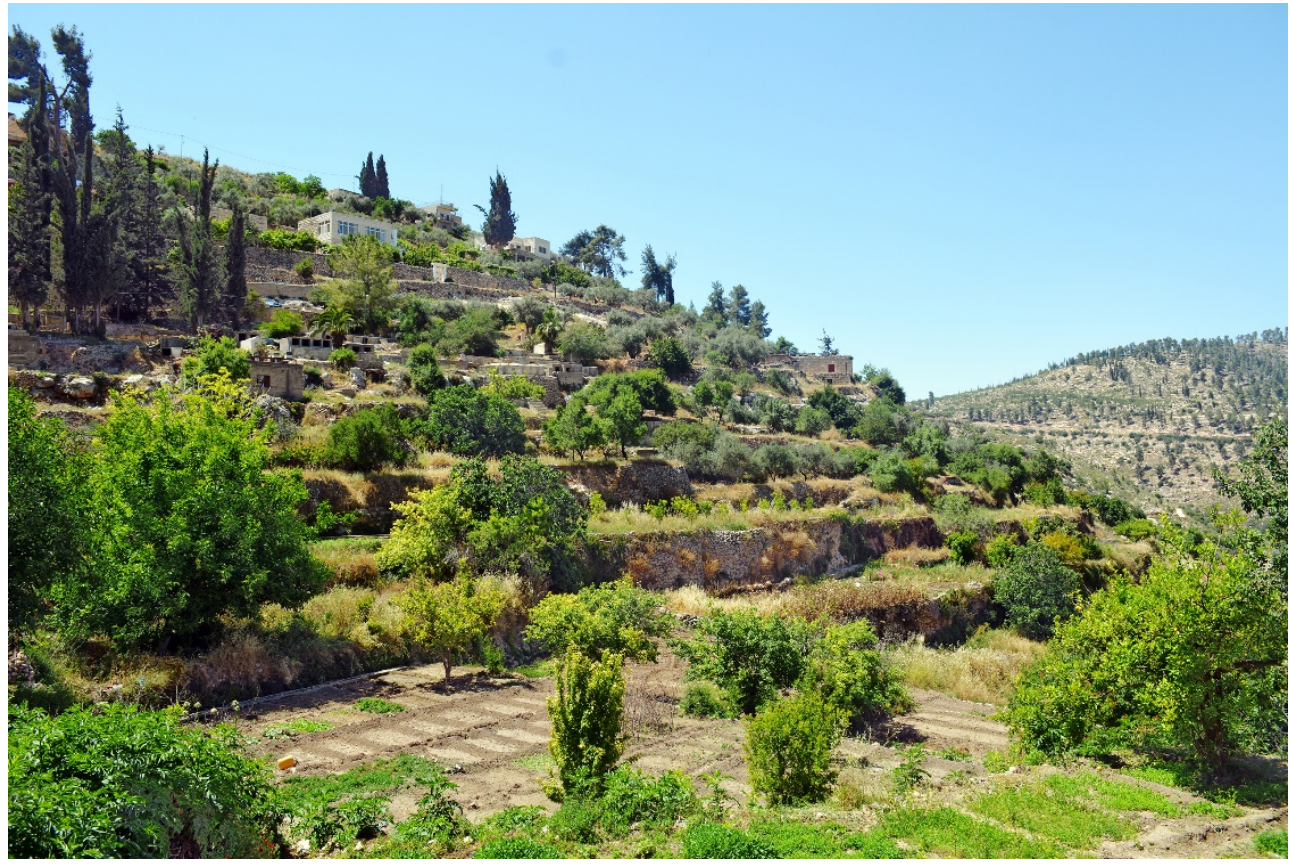

Fig. 7 - A view of landscape in the nearby of the village of Battir. 


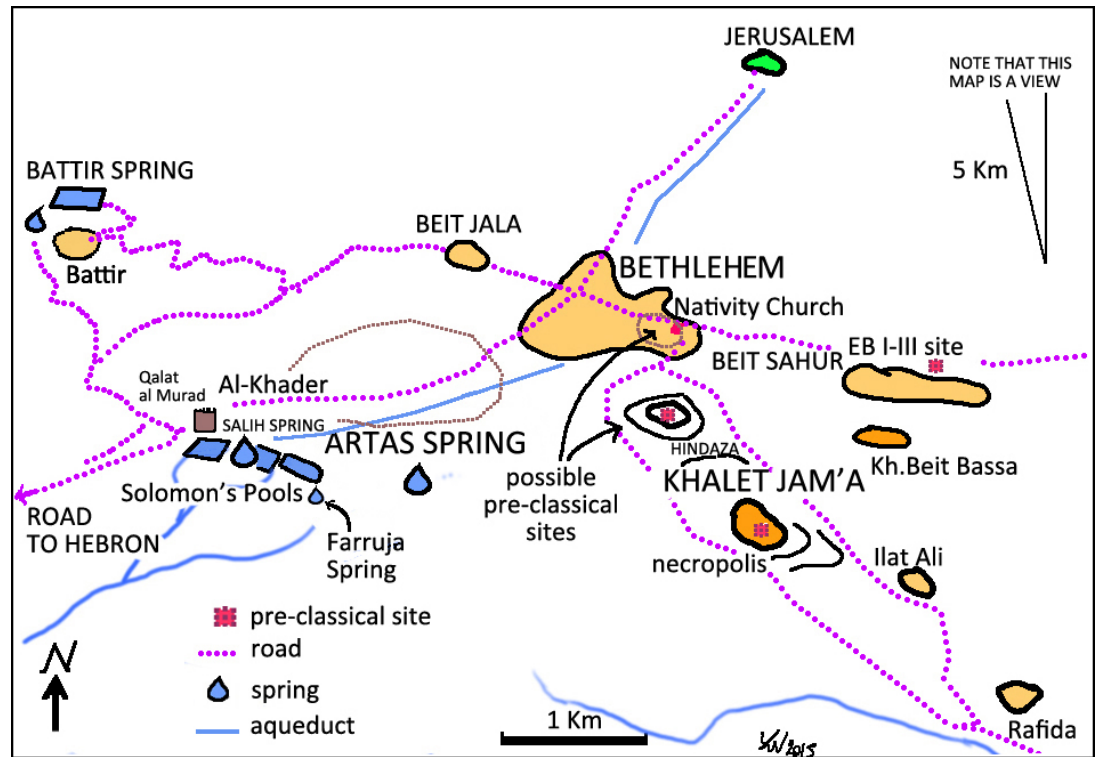

Fig. 8 - Major sites and springs in Bethlehem and its environs.

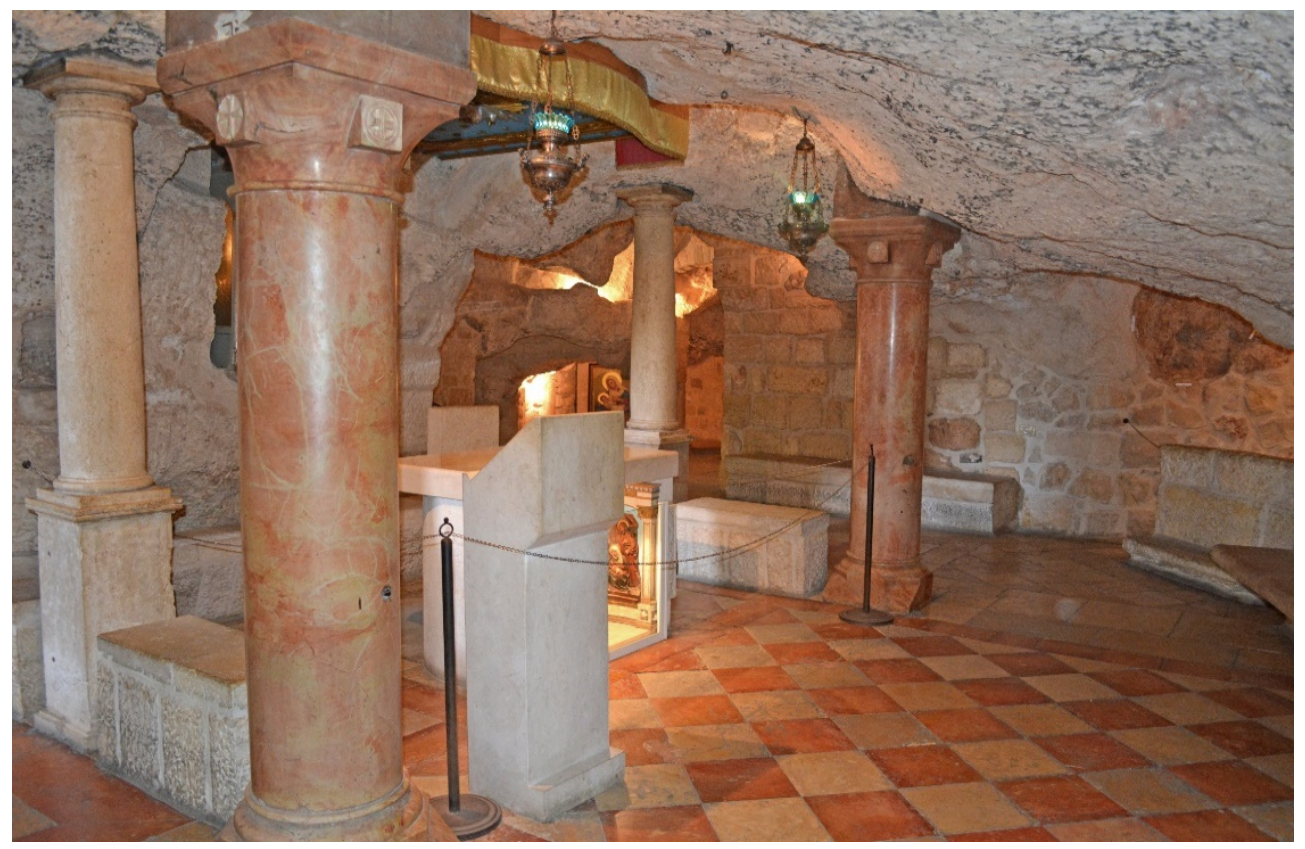

Fig. 9 - Interior of the 'Milk Grotto'. 


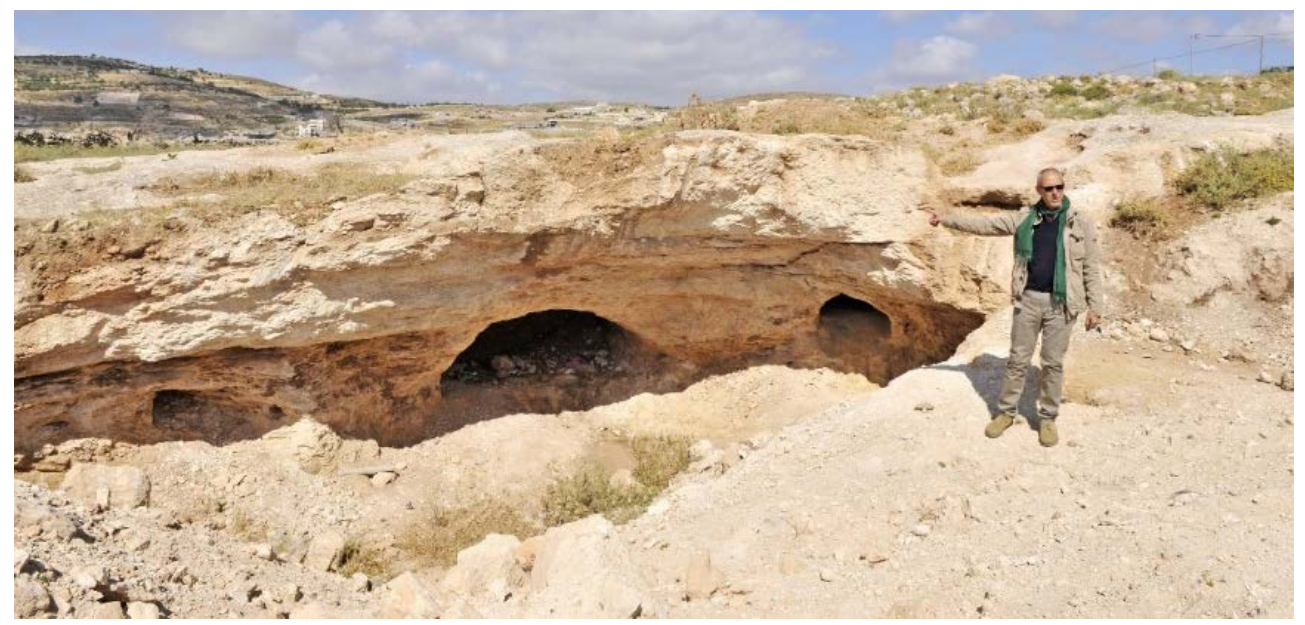

Fig. 10 - Area A of the newly discovered necropolis of Khalet al-Jam’a in Spring 2015.

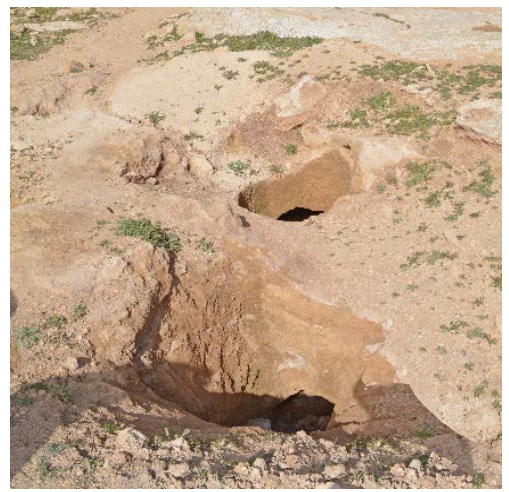

Fig. 11 - Shafts of Tomb A2 (foreground) and the northern uppermost terrace, Area D (background), of the necropolis; from the south-west.

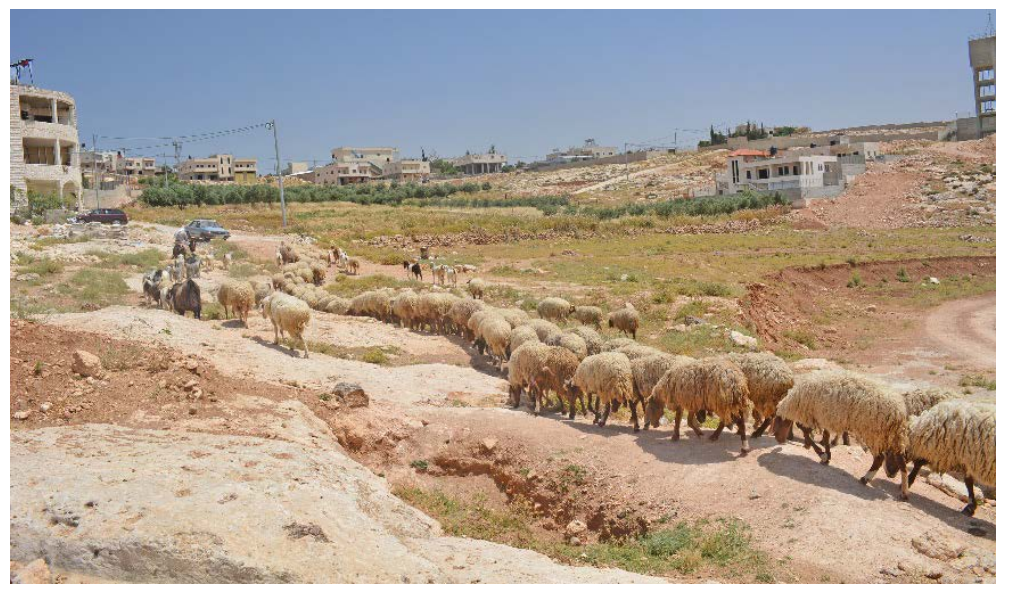

Fig. 12 - A view of the necropolis during Spring 2015. 
Fig. 13 - Tomb B9 in Khalet al-Jam'a necropolis cut into half by building activities.

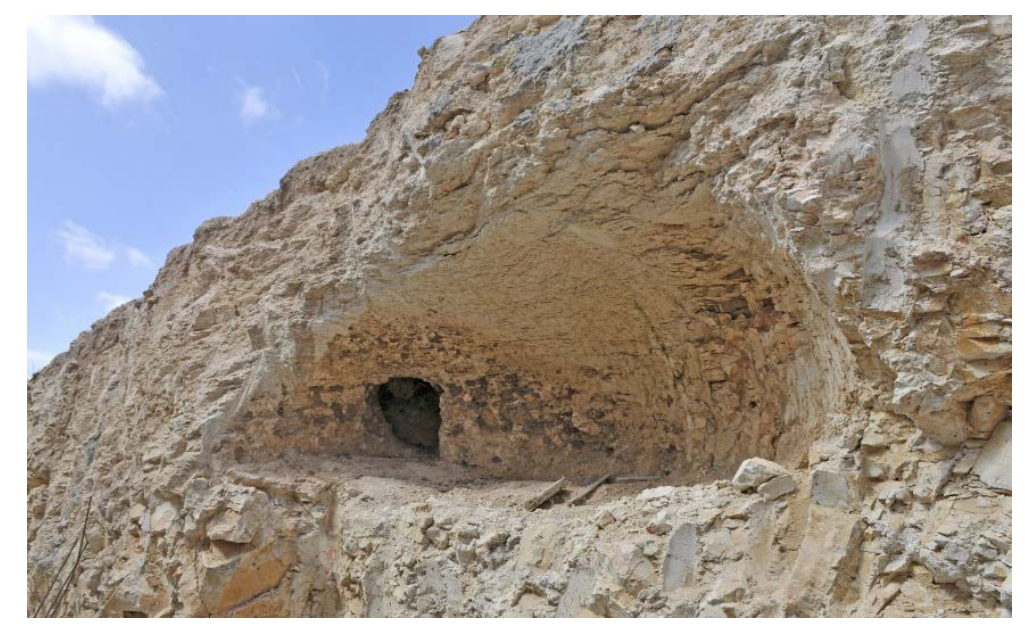

Fig. 14 - MB II pottery equipment in situ in Tomb A2.

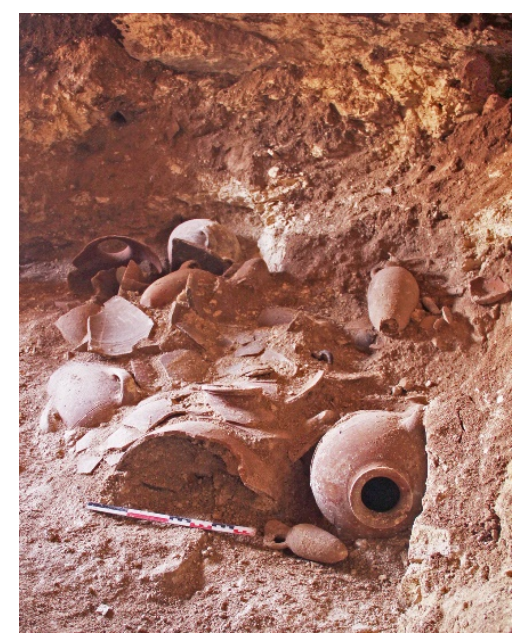

Fig. 15 - MB II funerary set of Tomb A2 in Khalet al-Jam'a necropolis.

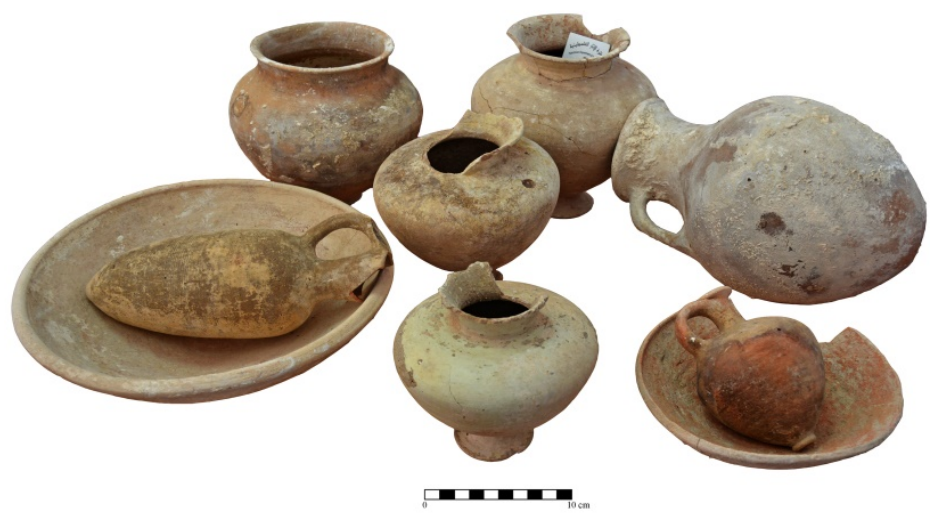




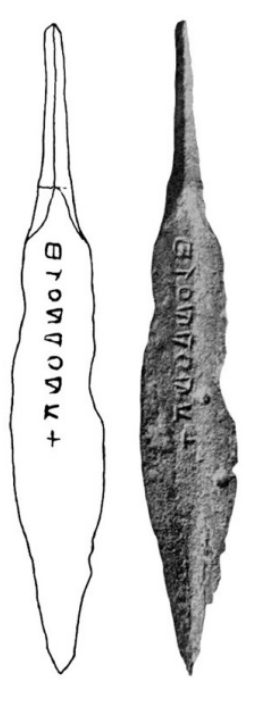

I

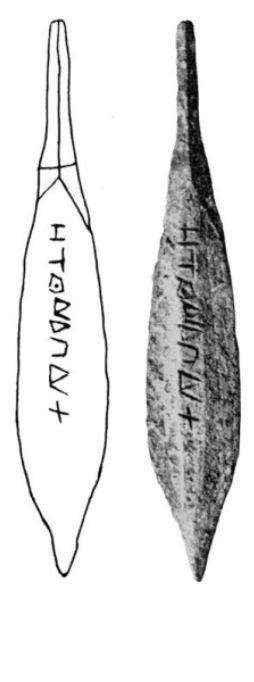

II

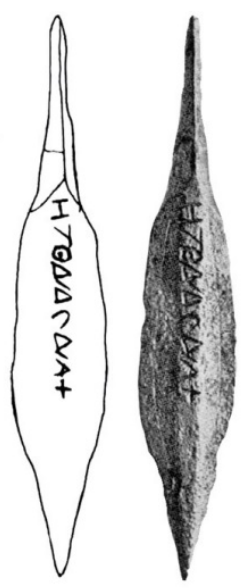

III

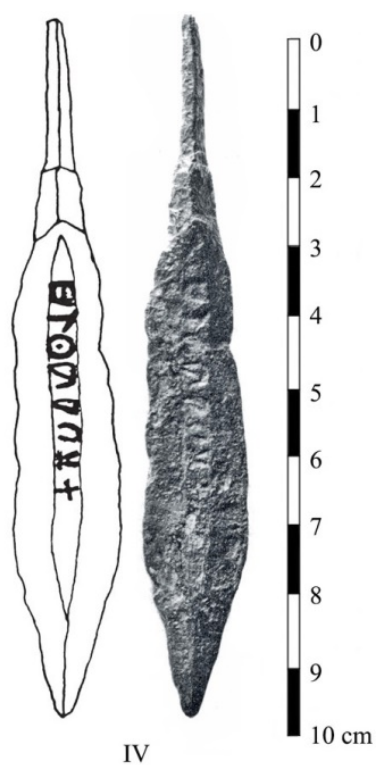

IV

a)
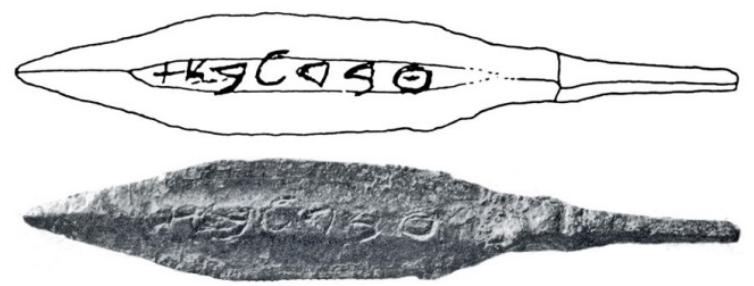

b)

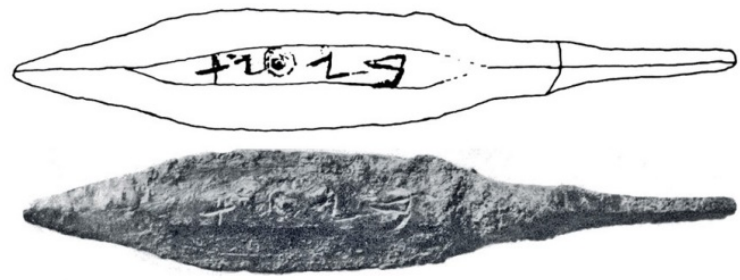

V

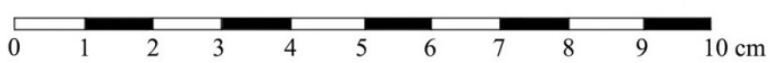

Fig. 16 - Inscribed arrowheads from el-Khadr. Four arrowheads (I-IV) bear the vertical inscription: hṣ 'bal' t/ḥiṣ 'abdla<b>i't, "The arrowhead of 'Abdla<bi>'at"; the fifth arrowhead (V) bears the horizontal inscription: a) 'bdlb’t/‘Abdlabi’t (obverse), b) bn 'nt/bin 'Anāt (reverse), "“Abdlabi'at son of 'Anat" (Milik - Cross 1954, 6-8, fig. 1; Cross 1980, 47, figs. 3-8; Naveh 1982, 37-39, fig. 32). 

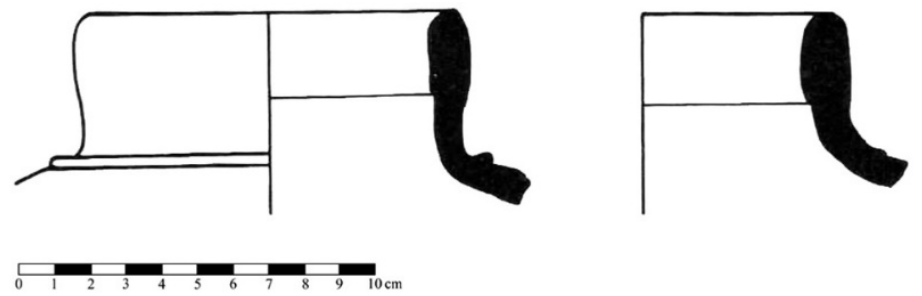

Fig. 17 - Two collared rim jars found in the excavations of "David's Wells" (after Bagatti Alliata 1968, fig. 4, ns. 1-2).
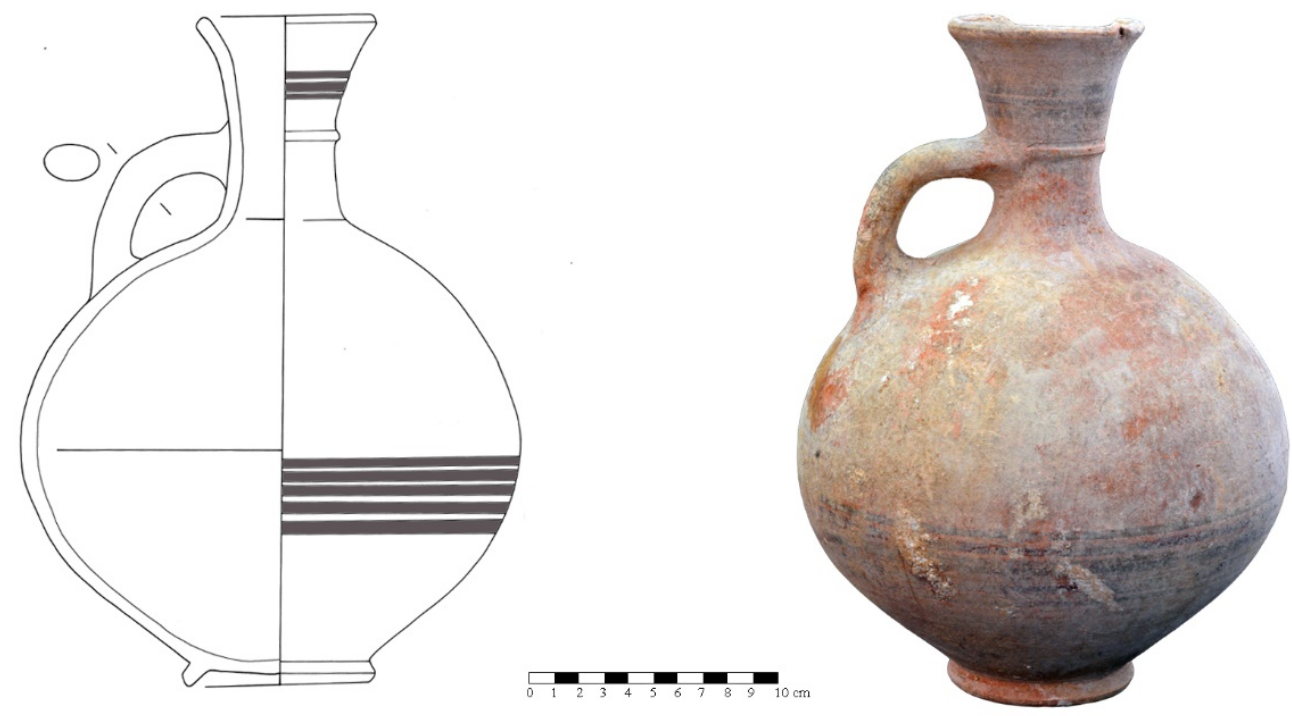

Fig. 18 - Jug 6182 from the Iron Age II Barmil’s Tomb of Khalet al-Jam'a.

Fig. 19 - The bulla possibly mentioning ( $2^{\text {nd }}$ line) Beth Lehem recently retrieved in Jerusalem (http://www.antiquities.org.il).

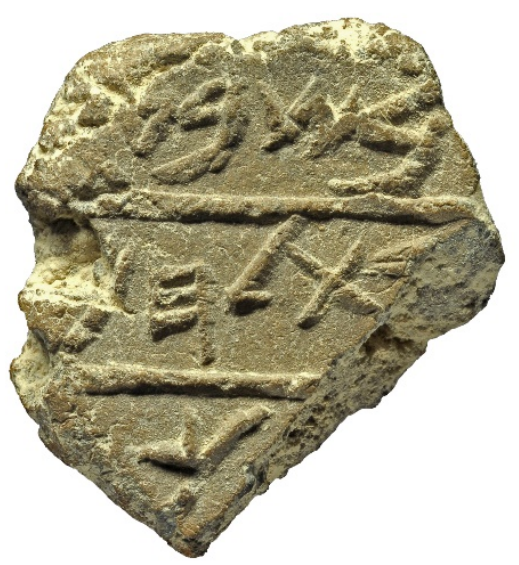



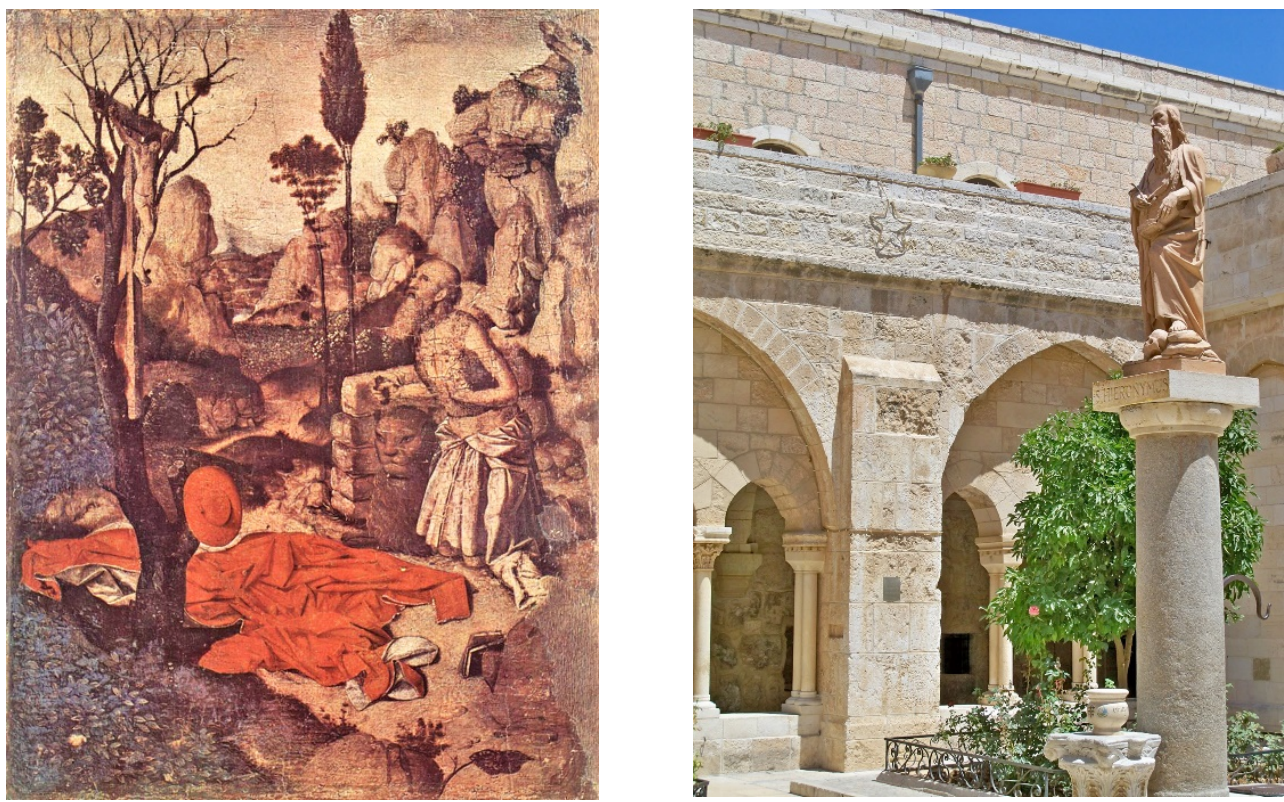

Fig. 20 - San Girolamo penitente (Antonello da Messina, Museo della Magna Grecia, Reggio Calabria), on the left; the statue of St. Jerome in the cloister of Monastery of Saint Catherine in Bethlehem, on the right. 


\section{SOMMARIO}

DipartimENTo SCIENZE DELl'ANTICHITÀ

SEZIONE di ORIENTALISTICA

\section{VICINO ORIENTE \\ XIX - 2015}

L. Nigro - Bethlehem in the Bronze and lron Ages
in the light of recent discoveries by the Palestinian MOTA-DACH

$\checkmark$. Pisaniello - Parallel passages among Hittite-Luwian rituals:

for the restoration of $K U B 35.146$

F. Spagnoli - Una testa di sileno in bronzo da Mozia

N. Chiaren

dall Area sacra del Kothon a Mozia

G. Labisi - al-Fudayn: an Umayyad residence in Northern Jordan

P. Buzi - Early Christianity in the Fayyūm: the new contribution of archaeology

I. Materia - Preliminary notes on the ware depicted on the ceiling

of the Cappella Palatina in Palermo

S. Autiero - Indian Ocean trade:

a reassessment of the pottery find
$\left(3^{\text {rd }}\right.$ century $B C-S^{S^{t h}}$ century $\left.A D\right)$

M.M. Jamhawi - N. Al-Shakarchi - I. Al-Hashimi

Assessment of tourists' satisfaction in the downtown of Amman

SCAVI E RICERCHE

L. Nigro - C. Fiaccavento - M. Jaradat - J. Yasine

A

L. Nigro - D. Montanari - M. Ghayyada - J. Yasine

A Middle Bronze and Iron Age necropolis near Bethlehem (Palestine)

L. Nigro - G. Ripepi - I. Hamdan - J. Yasine

15 Interim Report

and valorization of archaeological heritage

R. Francia - L'archivio di tavolette del complesso B-C-H di Büyükkale

organizazione degli archivi reali ittiti. Considerazioni preliminari

V. Pisaniello - La collezione di tavolette del complesso B-C-H di Büyükkale

T. De Vincenzi - L'archivio di tavolette del complesso B-C-H
sull'acropoli di Büyükkale

Museo del Vicino Oriente, Egitto e Mediterraneo

L. Nigro - Il nuovo allestimento del Museo del Vicino Oriente,

Egitto e Mediterraneo della Sapienza

D. Montanari - Bollettino delle attività del Museo del Vicino Oriente,

Egito e Meditraneo della Sapienza, anno 2015

RECENSIONI

A. Orsingher - E. PAPPA (2013), Early Iron Age Exchange in the West:

(Ancient Near Eastern Studies Supplement Series 43)

Leuven - Paris - Walpole 2013, MA.: Peeters $\frac{1}{2}$

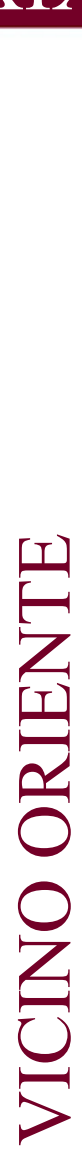

345

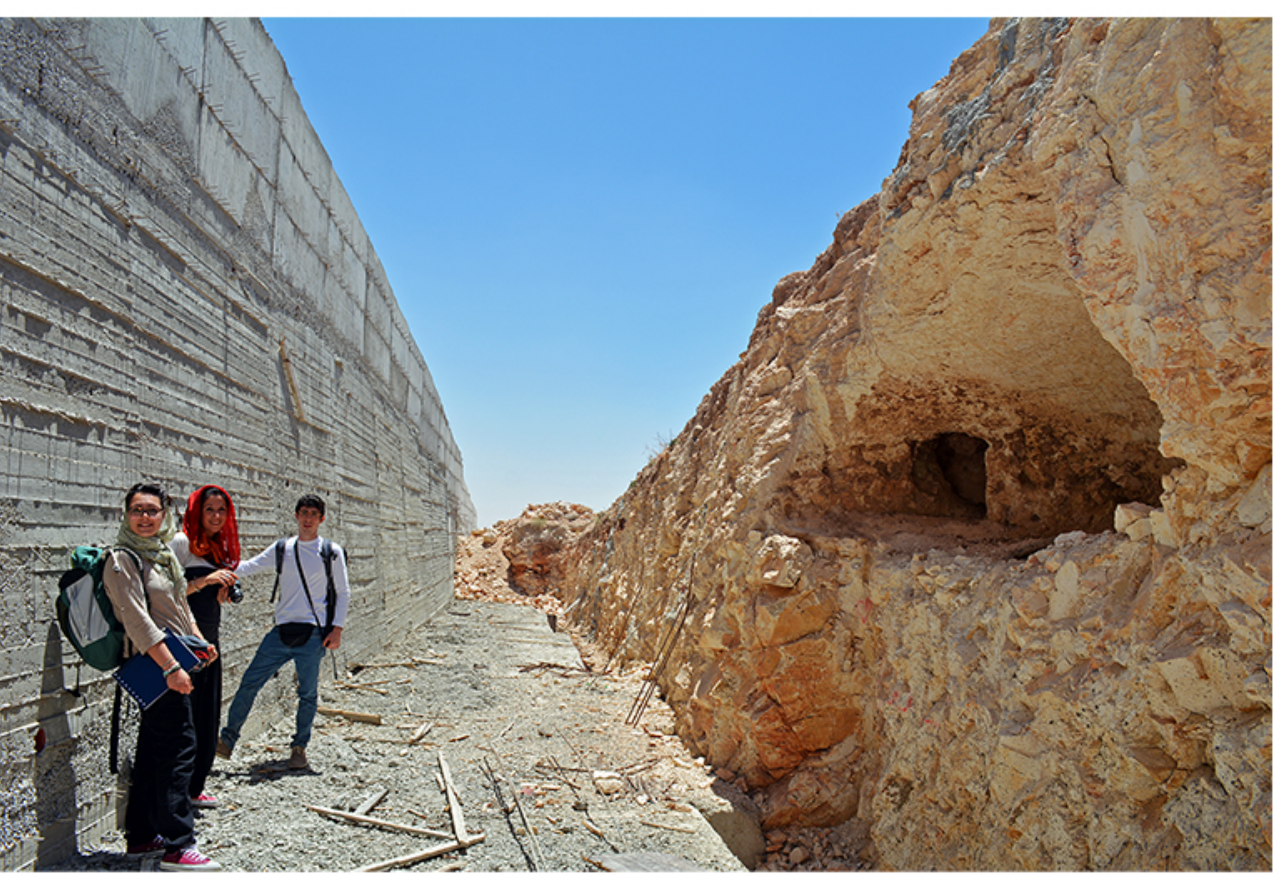

ROMA 2015 


\section{VICINO ORIENTE XIX - 2015}


VICINO ORIENTE

SAPIENZA UNIVERSITÀ DI ROMA

DIPARTIMENTO SCIENZE DELL'ANTICHITÀ

SEZIONE DI ORIENTALISTICA

Scientific Editor: Lorenzo Nigro

International Scientific Committee: Brian Rose, Frank Braemer, Mounir Fantar, Piero Bartoloni, Thomas Schaefer, Zeidan Kafafi

National Scientific Committee: Carlo Giovanni Cereti, Maria Vittoria Fontana, Sebastiano Tusa, Massimiliano Marazzi

Editorial Board: Daria Montanari, Chiara Fiaccavento

Tipografia: SK7 - Roma

ISSN 0393-0300

Rivista con comitato di referee

Journal with international referee system

www.lasapienzatojericho.it/SitoRivista/Journal/Rivista.php

In copertina: Tomba B9, necropoli di Khalet al-Jam’a (Betlemme). 
VICINO ORIENTE

SAPIENZA UNIVERSITÀ DI ROMA

DIPARTIMENTO SCIENZE DELL'ANTICHITÀ

SEZIONE DI ORIENTALISTICA

\section{SOMMARIO}

ARTICOLI

L. Nigro - Bethlehem in the Bronze and Iron Ages

in the light of recent discoveries by the Palestinian MOTA-DACH

V. Pisaniello - Parallel passages among Hittite-Luwian rituals:

for the restoration of KUB 35.146

F. Spagnoli - Una testa di sileno in bronzo da Mozia

N. Chiarenza - Una matrice per terrecotte con sileno dall'Area sacra del Kothon a Mozia

G. Labisi - al-Fudayn: an Umayyad residence in Northern Jordan

P. Buzi - Early Christianity in the Fayyūm: the new contribution of archaeology

I. Materia - Preliminary notes on the ware depicted on the ceiling

of the Cappella Palatina in Palermo

S. Autiero - Indian Ocean trade:

a reassessment of the pottery finds from a multidisciplinary point of view ( $3^{\text {rd }}$ century $B C-5^{\text {th }}$ century $\left.A D\right)$

M.M. Jamhawi - N. Al-Shakarchi - I. Al-Hashimi

Assessment of tourists' satisfaction in the downtown of Amman

SCAVI E RICERCHE

L. Nigro - C. Fiaccavento - M. Jaradat - J. Yasine Archaeology from A to Z: Abu Zarad, an ancient town in the heartland of Palestine

L. Nigro - D. Montanari - M. Ghayyada - J. Yasine

Khalet al-Jam'a. A Middle Bronze and Iron Age necropolis near Bethlehem (Palestine) 185 
VICINO ORIENTE

SAPIENZA UNIVERSITÀ DI ROMA

DIPARTIMENTO SCIENZE DELL'ANTICHITÀ

SEZIONE DI ORIENTALISTICA

L. Nigro - G. Ripepi - I. Hamdan - J. Yasine

The Jericho Oasis Archaeological Park - 2015 Interim Report.

Italian-Palestinian Cooperation for protection

and valorization of archaeological heritage

R. Francia - L'archivio di tavolette del complesso B-C-H di Büyükkale

e l'organizzazione degli archivi reali ittiti. Considerazioni preliminari

V. Pisaniello - La collezione di tavolette del complesso B-C-H di Büyükkale

T. De Vincenzi - L'archivio di tavolette del complesso B-C-H sull'acropoli di Büyükkale

Museo del Vicino ORIente, Egitto e MediterRaneo

L. Nigro - Il nuovo allestimento del Museo del Vicino Oriente,

Egitto e Mediterraneo della Sapienza

D. Montanari - Bollettino delle attività del Museo del Vicino Oriente,

Egitto e Mediterraneo della Sapienza, anno 2015

\section{RECENSIONI}

A. Orsingher - E. PAPPA (2013), Early Iron Age Exchange in the West:

Phoenicians in the Mediterranean and the Atlantic

(Ancient Near Eastern Studies Supplement Series 43),

Leuven - Paris - Walpole 2013, MA.: Peeters 